\title{
Branched glycerol dialkyl glycerol tetraethers and paleoenviron- mental reconstruction in Zoigê peat sediments during the last 150 years
}

\author{
ZHOU HaoDa $^{1,2}$, HU JianFang $^{1 *}$, MING LiLi $^{1,2}$, PENG Ping An $^{1} \&$ ZHANG Gan $^{1}$ \\ ${ }^{1}$ Guangzhou Institute of Geochemistry, Chinese Academy of Sciences, Guangzhou 510640, China; \\ ${ }^{2}$ Graduate University of Chinese Academy of Sciences, Beijing 100049, China
}

Received November 30, 2010; accepted April 6, 2011

\begin{abstract}
Branched glycerol dialkyl glycerol tetraethers (GDGTs) were analyzed in peat samples taken from the Zoigê grassland, located on the eastern margin of the Qinghai-Tibetan Plateau. The mean annual air temperature (MAAT) and $\mathrm{pH}$ in the ${ }^{210} \mathrm{~Pb}$-dating peat core were reconstructed based on the cyclization of branched tetraethers (CBT) and methylation of branched tetraethers (MBT) indices for the last 150 years. The results showed that the MAAT and $\mathrm{pH}$ values involved three stages of variation over the last 150 years. The $\mathrm{pH}$ was stable and the MAAT decreased slowly by about $1^{\circ} \mathrm{C}$ from 1851 to 1927 . The $\mathrm{pH}$ decreased rapidly by 0.6 and the MAAT decreased significantly by $2.5^{\circ} \mathrm{C}$ between 1927 and 1979 . The $\mathrm{pH}$ and MAAT increased by 0.8 and $5^{\circ} \mathrm{C}$, respectively, since the 1980s. The reconstructed temperatures correspond well to the mean winter temperatures reconstructed using tree-rings from the Jiuzhaigou Valley, situated at the boundary between the Qinghai-Tibetan Plateau and the Sichuan Basin. The estimated MAAT was similar to the temperatures reconstructed using tree-rings, indicating an increasing trend, as shown by local instrumental records from 1957 to 2001 . These results provide further confidence in the application of proxies based on glycerol dialkyl glycerol tetraethers in peat records for continental paleoclimate reconstruction.
\end{abstract}

peat, Zoigê grassland, methylation of branched tetraethers, cyclization of branched tetraethers, mean annual air temperature, paleoclimate, paleoenvironment

Citation: Zhou H D, Hu J F, Ming L L, et al. Branched glycerol dialkyl glycerol tetraethers and paleoenvironmental reconstruction in Zoigê peat sediments during the last 150 years. Chinese Sci Bull, 2011, 56: 2456-2463, doi: 10.1007/s11434-011-4594-9

Reconstructions of paleoclimates and paleoenvironments can help us to better understand the variation processes and mechanisms of the Earth's systems and effectively reduce the uncertainties in these predictions by providing a basis for climatic and environmental predictions. Ice-core, loess, tree-ring, coral, and marine and lacustrine sedimentary records have been used for paleoclimate reconstruction. The key to establishing high-resolution climatic and environmental sequences ingeological history is to search for sensitive climatic and environmental proxies. Peat core sediments are also an important geological record. Peat core sediments are mainly accumulated in situ by plant remains

*Corresponding author (email: hujf@gig.ac.cn) and the burying process is relatively simple. The organic-matter content of these plant remains is relatively abundant, thus the remains are a good indicator to study the paleoenvironment/paleoclimate in terms of molecular organic geochemistry data.

Lipids (n-alkane, fatty alcohol, fatty acid, sterone, triterpenoid and linear-chain ester) in peat core sediments, isotopes of $\mathrm{C}, \mathrm{H}$, and $\mathrm{O}$ in celluloses, peat core humification rates and sporopollen fossils are good biomarkers for paleoenvironmental reconstructions [1-8]. Although these climatic proxies can be used to reconstruct paleoenvironments, providing information about changes in the paleoenvironment/paleoclimate (dry or wet, cold or warm), they cannot be used to calculate temperature values quantitatively. 
Moreover, most proxies show an indeterminate relationship with environmental factors (temperature, precipitation and $\mathrm{CO}_{2}$ partial pressure); hence future work is needed to perfect these.

In recent years, the methylation of branched tetraethers (MBT) index and the cyclization of branched tetraethers (CBT) ratio, based on the distribution of glycerol dialkyl glycerol tetraethers (GDGTs), have been developed [9-12]. At present, two classes of GDGTs, namely isoprenoid GDGTs (GDGT-0-GDGT-4 and crenarchaeol) and branched GDGTs (I-III) (their molecular structures are shown in Figure 1), are being extensively studied. Isoprenoid GDGTs are biosynthesized exclusively by Archaea and are one of the biomarkers of Archaea [13]. The exact origin of the branched GDGTs is ambiguous, but it is likely that branched GDGTs are produced by bacteria in soil and peat [14]. Weijers et al. [9] described the relationship between the relative distributions of branched GDGTs and local environmental factors (temperature and $\mathrm{pH}$ ) using 134 globally distributed soil samples from 90 different locations and showed that mean annual air temperature (MAAT) and soil $\mathrm{pH}$ were the major factors affecting the distribution of GDGTs. The amount of cyclopentane in the branched GDGTs is related to soil $\mathrm{pH}$, whereas that of methyl groups is related to both MAAT and soil $\mathrm{pH}$. Based on these observations, two indices were proposed for quantifying the distributions of branched GDGTs: the CBT index, reflecting soil $\mathrm{pH}$, and the MBT index for both MAAT and soil $\mathrm{pH}$. The indices are defined in formulas 1-4.

Peterse et al. [12] determined these indices for soils sam- pled from a transect in the peripheries of two hot springs in California. The CBT values of these geothermally heated soils showed good correlation with $\mathrm{pH}\left(R^{2}=0.76\right)$, also the relationship between MBT, soil $\mathrm{pH}$ and temperature for the geothermally heated soils was similar to that of the global data set [9]. The results confirmed the dependence of the MBT index on soil temperature and $\mathrm{pH}$ and supported the applicability of the MBT/CBT indices as proxies for continental paleotemperatures and soil $\mathrm{pH}$ values in the past. Branched GDGTs have been used to reconstruct continental temperatures and soil $\mathrm{pH}$ values for several areas and geological times, for example, the last glacial-interglacial transition period in the Congo Basin, Africa [15], the Paleocene-Eocene thermal maximum from Arctic Ocean sediments [16], and at the Oligocene-Eocene boundary in Greenland [11]. Furthermore, Peterse et al. [17] applied these proxies to paleoclimate reconstruction in high-latitude environments with a MAAT of $<0^{\circ} \mathrm{C}$. Although branched GDGT concentrations in the soil are relatively low, reconstructed MAATs based on the MBT/CBT proxies are ca. $-4^{\circ} \mathrm{C}$, close to the measured MAAT (ca. $-6^{\circ} \mathrm{C}$ ).

In this study, we measured the GDGT contents in Zoigê peat samples, calculated the MBT and CBT proxies by applying them to a peat core, and compared the estimates for the last 150 years with regional instrumental records of air temperatures and $\mathrm{pH}$. The results provided some heuristic data for reconstruction of the continental paleoenvironment. The precisions of CBT and MBT computation are 0.014 and 0.008 , respectively, and those of the $\mathrm{pH}$ and MAAT values obtained by conversion are \pm 0.04 and $\pm 0.3^{\circ} \mathrm{C}$, respectively.

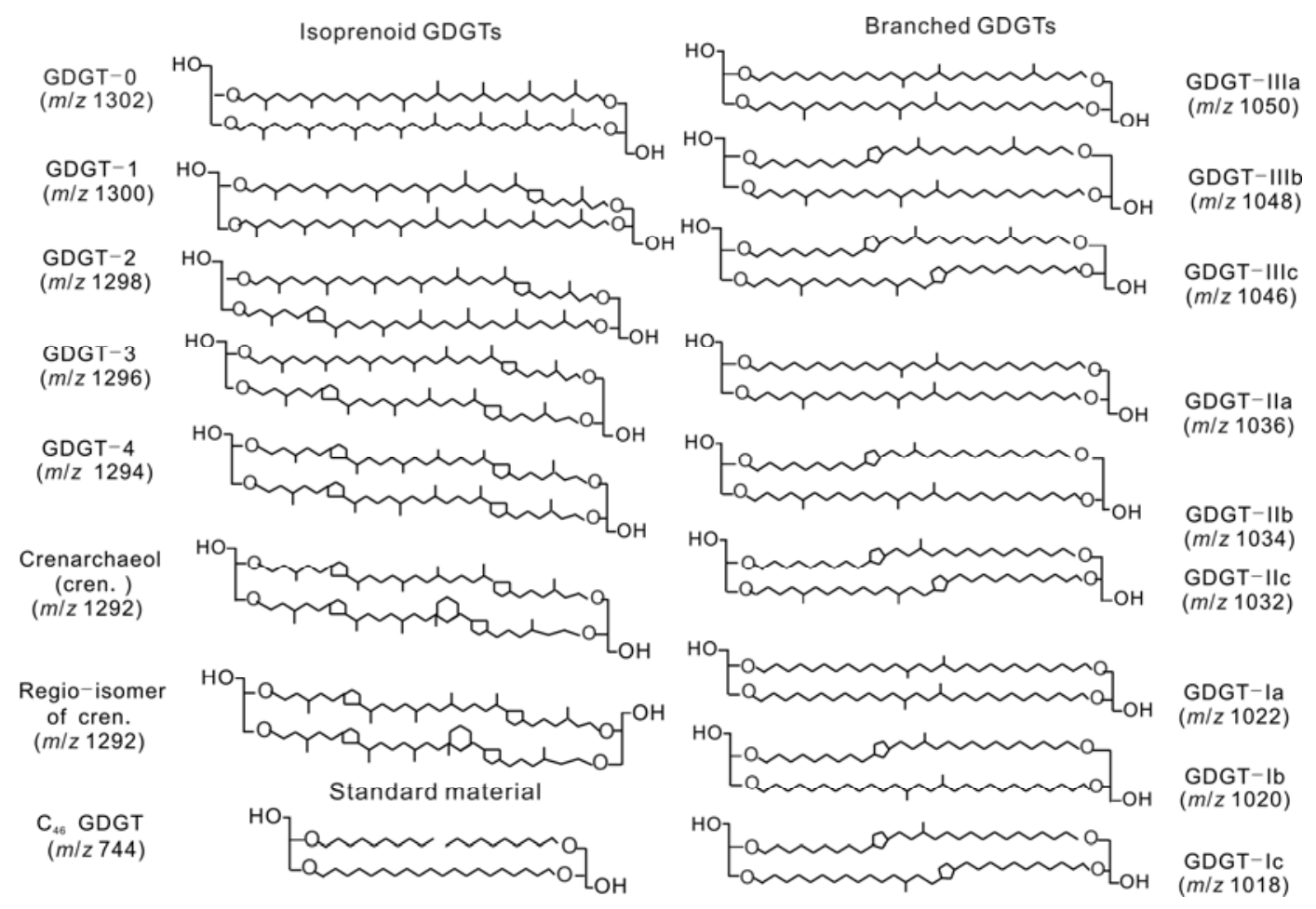

Figure 1 Molecular structures of isoprenoid and branched GDGTs. 


\section{Materials and methods}

\subsection{Sampling and dating}

The Hongyuan peat is located on the eastern edge of the Qinghai-Tibetan Plateau, in the northeast of Sichuan, in the middle of the Ngawa Tibetan and Qiang Autonomous Prefecture; it is situated in China's biggest moss-land plateau the Zoigê peat area. It is a subalpine meadow prairie belt consisting of herbaceous peat $[18,19]$. In the Hongyuan area, the prevailing climate is a monsoon climate characteristic of a continental plateau in a frigid-temperate zone, with short spring and autumn periods, long winters, and no summer. In this area, the annual mean temperature is $0.6-1.2^{\circ} \mathrm{C}$ and the annual mean precipitation is $560-860 \mathrm{~mm}$. The climate is further characterized by a great difference in temperature between day and night, sufficient rainfall, and contemporaneous rainy and hot seasons $[19,20]$.

The sampling site $\left(32^{\circ} 46^{\prime} \mathrm{N}, 102^{\circ} 30^{\prime} \mathrm{E}\right)$ is located $2 \mathrm{~km}$ west of Hongyuan County in the Zoigê peat-core area in Hongyuan, Sichuan, at an altitude of $3510 \mathrm{~m}$ above sea level. The sampling tool was a stainless steel Wardenaar. The sample column was $25 \mathrm{~cm}$ long. The whole sample column was put into a PVC tube and kept at $-10^{\circ} \mathrm{C}$ in the laboratory. The sample was divided longitudinally into two parts: one was used for ${ }^{210} \mathrm{~Pb}$ dating, and the other (subsampled at intervals of $0.5 \mathrm{~cm}$ ) was used for GDGTs testing.

The age model was established using ${ }^{210} \mathrm{~Pb}$ data from the Nanjing Institute of Geography and Limnology, Chinese Academy of Sciences (Figure 2), and the sample core was dated in the constant initial concentration mode [21-24].

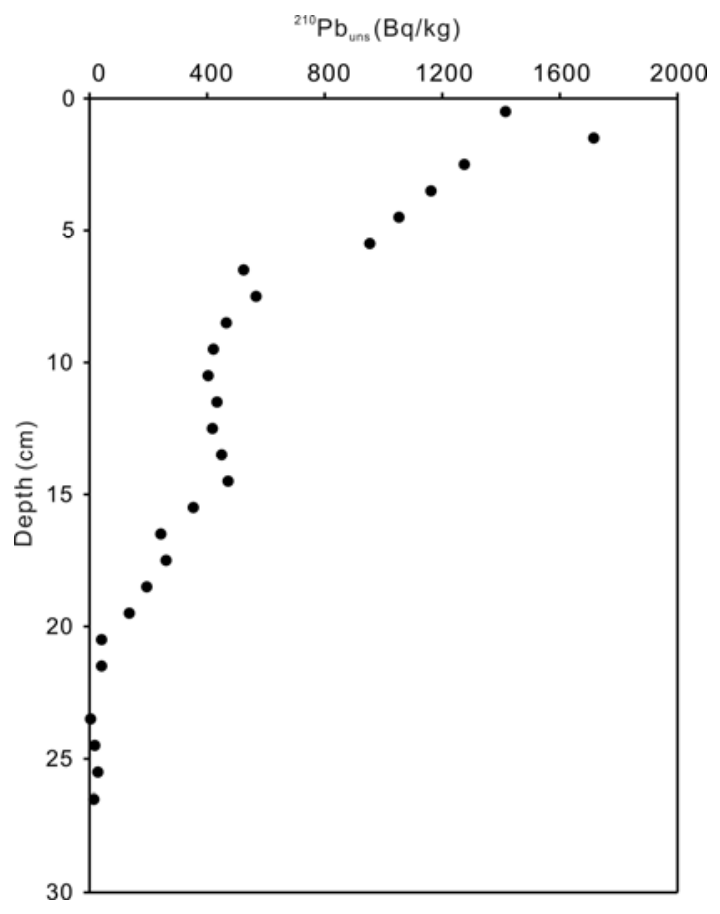

Figure $2{ }^{210} \mathrm{~Pb}_{\text {uns }}$ profile (uns: unsupported. The amount of ${ }^{210} \mathrm{~Pb}_{\text {uns }}$ in a sediment sample can be calculated by measuring both ${ }^{210} \mathrm{~Pb}$ and ${ }^{226} \mathrm{Ra}$ ).
The precipitation rate is $0.16 \mathrm{~cm} / \mathrm{a}$, and the sample core time span is $1851-2006$.

\subsection{Methods}

(i) Pretreatment method. Samples for lipid analysis were freeze dried and powdered with a mortar and pestle prior to extraction. Approximately $500 \mathrm{mg}$ of freeze-dried sample, with a moderate amount of $\mathrm{C}_{46}$-GDGT (standard material, see the structure in Figure 1), were extracted by Soxhlet extraction with dichloromethane (DCM)/methanol $(\mathrm{MeOH})$ $(2 / 1, v / v)$ for $72 \mathrm{~h}$. The solvent was evaporated and the extract was separated by $\mathrm{Al}_{2} \mathrm{O}_{3}$ column chromatography with hexane/DCM (9/1, v/v) and DCM/MeOH (1/1, v/v) as sequential eluents. The polar fraction $(\mathrm{DCM} / \mathrm{MeOH})$ was concentrated by rotary evaporation, redissolved in hexane/isopropanol (99/1, v/v), and filtered using a PTFE 0.45 $\mu \mathrm{m}$ filter. The filtrate was tested by high-performance liquid chromatography/atmospheric pressure chemical ionization -mass spectrometry (HPLC/APCI-MS).

(ii) Instrumental methods. The HPLC/MS method used was modified from that described by Hopmans et al. [25], as discussed by Schouten et al. [26].

(1) Chromatography conditions. Analyses were performed using an Agilent 1200 series liquid chromatograph equipped with an auto-injector and ChemStation chromatography management software. Separation was effected with a Prevail Cyano column $(2.1 \mathrm{~mm} \times 150 \mathrm{~mm}, 3 \mu \mathrm{m}$; Alltech, Deerfield, USA) kept at $30^{\circ} \mathrm{C}$. The injection volume was $3 \mu \mathrm{L}$. GDGTs were eluted isocratically with $99 \%$ hexane and $1 \%$ propanol for $5 \mathrm{~min}$, followed by a linear gradient to $2 \%$ propanol over $40 \mathrm{~min}$. The flow rate was 0.2 $\mathrm{mL} / \mathrm{min}$. After each analysis, the column was cleaned by back-flushing hexane/propanol $(90: 10, \mathrm{v} / \mathrm{v})$ at $0.2 \mathrm{~mL} / \mathrm{min}$ for $15 \mathrm{~min}$.

(2) Mass spectrometry conditions. Detection was achieved using atmospheric pressure, positive ion chemical ionization-Agilent 6410 triple quad mass spectrometer (APCI-MS). The conditions were: nebulizer pressure $60 \mathrm{psi}$; vaporizer temperature $300^{\circ} \mathrm{C}$; drying gas $\left(\mathrm{N}_{2}\right)$, flow rate 5 $\mathrm{L} / \mathrm{min}$, temperature $200^{\circ} \mathrm{C}$; capillary voltage $2500 \mathrm{~V}$; and corona $5 \mu \mathrm{A}$. GDGTs were detected via single-ion monitoring (SIM) of their $[\mathrm{M}+\mathrm{H}]^{+}$and $[\mathrm{M}+\mathrm{H}]^{+}+1$ [i.e. protonated molecular ions $(\mathrm{m} / \mathrm{z}$ values are shown in Figure 2$)$ and first isotope peak ions] and quantified by integration of the peak areas [26].

Absolute concentrations were calculated using a newly synthesized internal standard material $\left(\mathrm{C}_{46}\right.$-GDGT) (refer to the method described by Huguet [27]). The relative response factors (RRF) of each GDGT and the internal standard material were not measured, so only semi-quantitative results were achieved.

GDGT indices were calculated as follows [9], where the roman numerals correspond to the GDGT structures shown in Figure 1: 


$$
\begin{gathered}
\text { MBT }=\frac{([I a]+[I b]+[I c])}{([I a]+[I b]+[I c])+([I I a]+[I I b]+[I I c])}, \\
+([I I I a]+[I I I b]+[I I I c]) \\
\mathrm{CBT}=-\log \left(\frac{([I b]+[I I b])}{([I a]+[I I a])}\right), \\
\mathrm{CBT}=3.33-0.38 \times \mathrm{pH}, \\
\mathrm{MBT}=0.122+0.187 \times \mathrm{CBT}+0.020 \times \text { MAAT } .
\end{gathered}
$$

\section{Results and discussion}

\subsection{GDGTs composition and structural characteristics in the profile}

Five isoprenoid and nine branched GDGTs were detected in the samples. The abundances of isoprenoid GDGTs are relatively low (0.001-0.63 $\mu \mathrm{g} / \mathrm{g}$, Figure 3(a)), accounting for about $3 \%$ of the total GDGTs, including GDGT-0, GDGT-1, GDGT-2, GDGT-3, and crenarchaeol. GDGT-0 is the most abundant isoprenoid GDGT, accounting for $62 \%-100 \%$ of the total isoprenoid GDGTs. Isoprenoid GDGTs possessing more than four cyclopentane groups were not examined. The above results are similar to those in the published literatures for soil and peat samples [9,28,29].

The concentrations of branched GDGTs vary between 1.8 and $20.3 \mu \mathrm{g} / \mathrm{g}$, accounting for $96 \%-100 \%$ of the total GDGTs (Figure 3(b)). The examined branched GDGTs are mainly GDTG-I, GDTG-II, and GDGT-III (Table 1), with the highest concentration being that of GDGT-II and the lowest concentration that of GDGT-III. The concentrations tend to decrease as the number of cyclopentane groups in the GDGTs changes from 0 to 2. Branched GDGTs were discovered in a Dutch Holocene peat deposit and identified by Sinninghe Damsté et al. [30]. Weijers et al. [14] found that the stereoconfigurations of the glycerol moieties of the membrane lipids were identical to those of the glycerol moieties synthesized by bacteria. Thus, it is likely that the branched GDGTs are produced by bacteria. Branched GDGTs occur ubiquitously in soils [31,32], peats [31], lakes, and coastal marine sediments [31,33] throughout the world. It was initially thought that all of the branched GDGTs in lakes and coastal marine sediments were deposited after being transported by rivers from land [34,35]. Recent studies suggest that at least part of the branched GDGTs in marine sediments may be produced in situ [17,36-38].

\section{$2.2 \mathrm{pH}$ and MAAT}

In recent years, branched GDGTs in marine sediments have been used to reconstruct continental paleotemperatures and soil $\mathrm{pH}$ values in the last glacial-interglacial transition period in the Congo Basin, Africa [16], in the Paleocene-Eocene thermal maximum from Arctic Ocean sediments [15], and at the Oligocene-Eocene boundary in Greenland [11]. Branched GDGTs in lake sediments have also been used to reconstruct paleoenvironments. For example, Zink et al. [39] found that the MBT index was a good tool for reconstructing continental paleotemperatures by comparing the distributions of branched GDGTs in lake

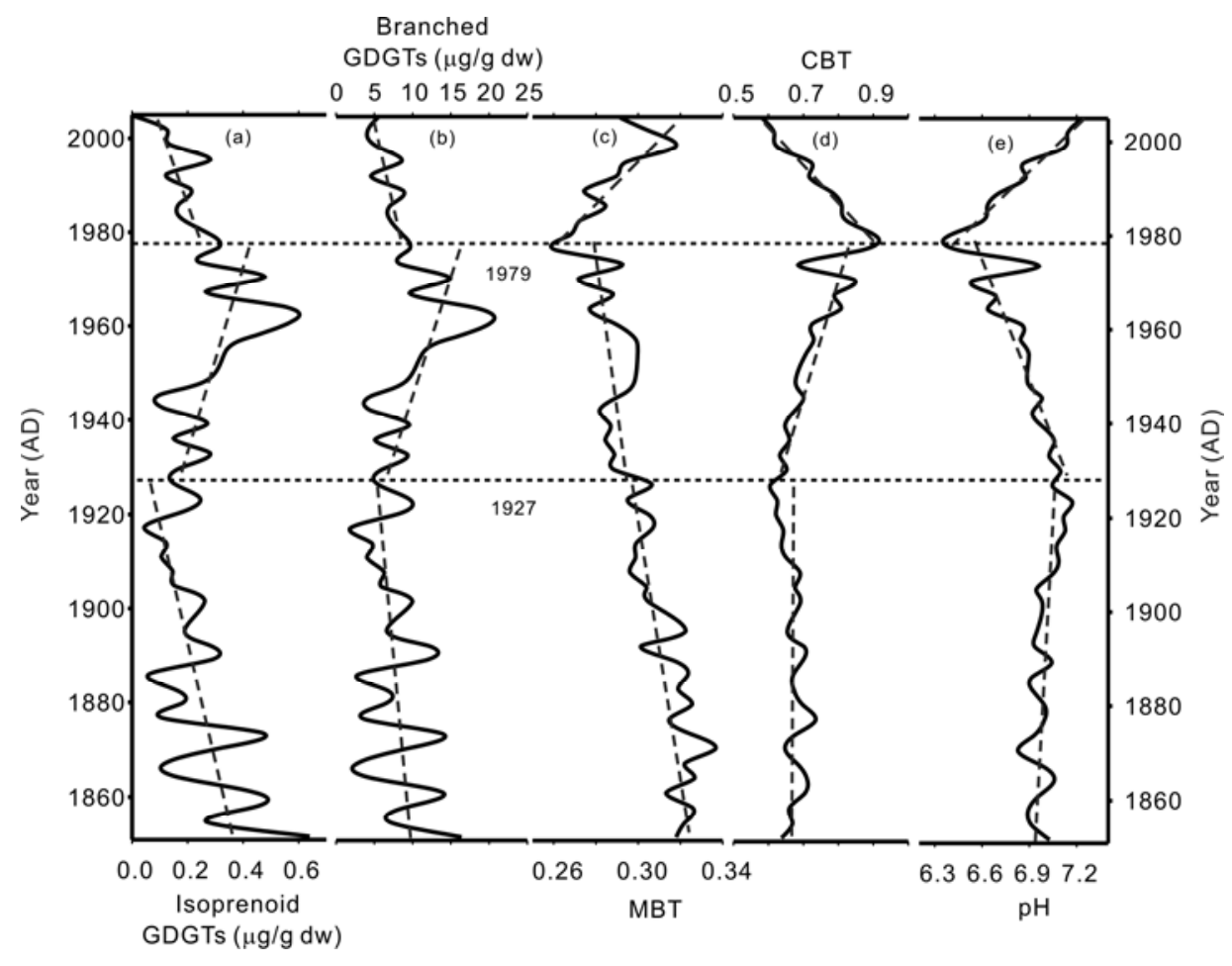

Figure 3 (a) Concentrations of isoprenoid GDGTs; (b) concentrations of branched GDGTs; (c) MBT; (d) CBT; (e) pH in the profile. 
deposits and recorded temperatures in New Zealand. Tyler et al. [36] reconstructed $\mathrm{pH}$ and MAAT values for approximately the past 400 years using a recent sedimentary GDGT profile from Lochnagar lacustrine deposits. The MBT/CBT proxies have been applied successfully to both marine and lacustrine deposits, but, to our knowledge, they have not been applied to the dating of peat-core deposits. In this research, we discussed the usefulness and potential application of these proxies in peat-core deposits.

In this research, the calculated CBT and MBT indices are $0.583-0.865$ and $0.260-0.337$, respectively (Figure 3(c) and (d)); Table 1). According to formulas (2) and (3), the $\mathrm{pH}$ values in the Zoige peat core for the last 150 years are within the range 6.4-7.2 (Figure 3(e)). The $\mathrm{pH}$ values of the remaining soils were measured according to standard methods, i.e. in a peat/water mixture $(1 / 2.5, \mathrm{~m} / \mathrm{v})$ [17]. The $\mathrm{pH}$ obtained by this method for the surface peat is 6.9 , i.e., slightly lower than the calculated result obtained using the CBT index (7.1). The values deduced from the CBT index suggest that the $\mathrm{pH}$ variations could involve three periods in the last 150 years: in the period 1851-1927, the $\mathrm{pH}$ was stable at 7.0, reflecting the situation in this area - an uninhabited peat area before 1930 [40]; in the period 1927-
1979, the $\mathrm{pH}$ decreased from 7.0 to 6.4, possibly because of deforestation in northwestern Sichuan Province, deforestation for farmland reclamation and the development of fire land since the 1920s [41], leading to extensive deposition of humus (mainly humic acid and fulvic acid); from 1979 to the present, the $\mathrm{pH}$ has increased by a large margin from 6.4 to 7.2. The steady increase in $\mathrm{pH}$ in the last 30 years could possibly be attributed to disturbance by human activities, resulting in decreased amounts of humic acid [42,43].

According to formula (4), the MAAT changed from $-0.4^{\circ} \mathrm{C}$ to $4.7^{\circ} \mathrm{C}$ (Figure $4(\mathrm{~d})$ ). The MAAT variation, as defined by the CBT/MBT indices, could also involve threeperiods in the last 150 years: in the period 1851-1927, the MAAT varied over a small range from $2.8^{\circ} \mathrm{C}$ to $3.8^{\circ} \mathrm{C}$ (decreasing slowly by approximately $1^{\circ} \mathrm{C}$ ); in the period 1927-1979, the MAAT varied between $-1.2^{\circ} \mathrm{C}$ and $2.4^{\circ} \mathrm{C}$, and reduced by $2.5^{\circ} \mathrm{C}$ at $0.05^{\circ} \mathrm{C} / \mathrm{a}$; from 1979 to the present, the MAAT varied between $-1.2^{\circ} \mathrm{C}$ and $3.9^{\circ} \mathrm{C}$, and increased rapidly by $5^{\circ} \mathrm{C}$ at $0.17^{\circ} \mathrm{C} / \mathrm{a}$. The variations in the calculated MAAT values showed the same tendency in a given time period (since 1949) as the annual mean temperature in China. However, the climate in the Zoigê grassland has obvious regional features because the area is located in the

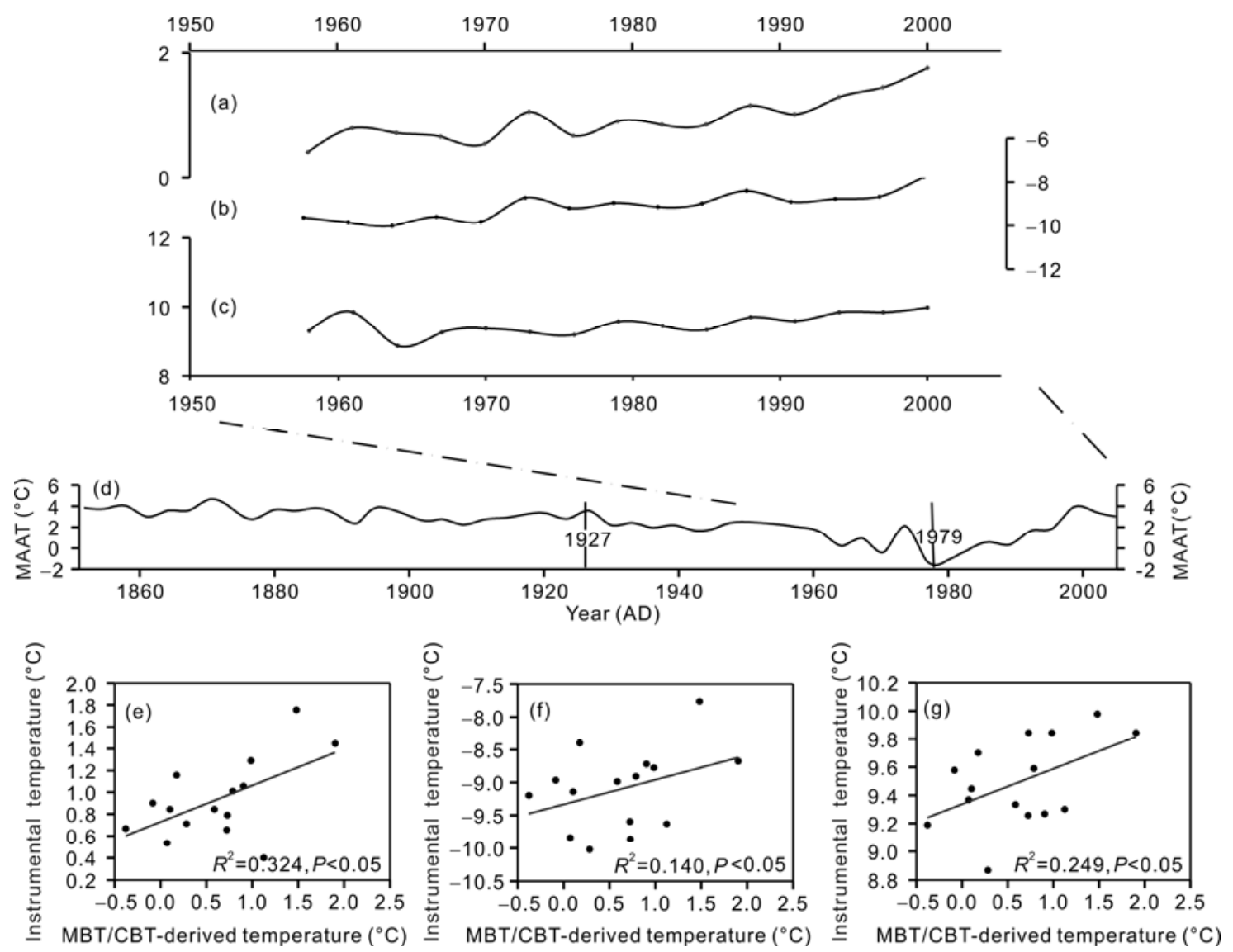

Figure 4 (a) MAAT values on a three-year scale; (b) average winter temperatures; (c) average summer temperatures from the Zoigê Weather Station [48]; (d) MAAT values calculated by MBT/CBT indices; (e) the correlation between instrumental MAAT and MAAT values calculated by MBT/CBT indices; (f) the correlation between average winter temperatures and MAAT values calculated by MBT/CBT indices; ( $\mathrm{g}$ ) the correlation between average summer temperatures and MAAT values calculated by MBT/CBT indices. 
Table 1 Concentrations of branched GDGTs in peat core

\begin{tabular}{|c|c|c|c|c|c|c|c|c|c|c|c|c|}
\hline \multirow{2}{*}{ Samples } & \multirow{2}{*}{ Depth $(\mathrm{cm})$} & \multicolumn{9}{|c|}{ Concentrations of branched GDGTs $(\mu \mathrm{g} / \mathrm{g} \mathrm{dw})$} & \multirow{2}{*}{ MBT } & \multirow{2}{*}{ CBT } \\
\hline & & Ic & $\mathrm{Ib}$ & Ia & IIc & $\mathrm{IIb}$ & IIa & IIIc & $\mathrm{IIIb}$ & IIIa & & \\
\hline HYS2-01 & 24.75 & 0.274 & 1.812 & 3.137 & 0.175 & 0.674 & 7.649 & $-{ }^{\text {a) }}$ & - & 2.704 & 0.318 & 0.637 \\
\hline HYS2-02 & 24.25 & 0.136 & 0.753 & 1.404 & 0.067 & 0.278 & 3.406 & - & - & 1.075 & 0.322 & 0.669 \\
\hline HYS2-03 & 23.75 & 0.171 & 0.948 & 1.806 & 0.092 & 0.357 & 4.152 & - & - & 1.455 & 0.326 & 0.659 \\
\hline HYS2-04 & 23.25 & 0.276 & 1.266 & 2.855 & 0.148 & 0.613 & 6.620 & - & - & 2.260 & 0.313 & 0.703 \\
\hline HYS2-05 & 22.75 & 0.087 & 0.444 & 0.992 & 0.050 & 0.177 & 2.195 & - & - & 0.718 & 0.327 & 0.711 \\
\hline HYS2-06 & 22.25 & 0.058 & 0.263 & 0.583 & 0.029 & 0.124 & 1.284 & - & - & 0.467 & 0.322 & 0.684 \\
\hline HYS2-07 & 21.75 & 0.191 & 0.964 & 1.970 & 0.099 & 0.424 & 4.204 & - & - & 1.429 & 0.337 & 0.648 \\
\hline HYS2-08 & 21.25 & 0.260 & 1.382 & 2.880 & 0.141 & 0.606 & 6.562 & - & - & 2.090 & 0.325 & 0.677 \\
\hline HYS2-09 & 20.75 & 0.067 & 0.314 & 0.768 & 0.036 & 0.148 & 1.741 & - & - & 0.576 & 0.315 & 0.735 \\
\hline HYS2-10 & 20.25 & 0.126 & 0.592 & 1.326 & 0.055 & 0.264 & 2.959 & - & - & 0.958 & 0.326 & 0.699 \\
\hline HYS2-11 & 19.75 & 0.122 & 0.663 & 1.274 & 0.072 & 0.253 & 3.047 & - & - & 1.025 & 0.319 & 0.674 \\
\hline HYS2-12 & 19.25 & 0.052 & 0.279 & 0.572 & 0.028 & 0.125 & 1.315 & - & - & 0.419 & 0.323 & 0.670 \\
\hline HYS2-13 & 18.75 & 0.233 & 1.067 & 2.402 & 0.109 & 0.532 & 5.556 & - & - & 1.791 & 0.317 & 0.697 \\
\hline HYS2-14 & 18.25 & 0.198 & 1.137 & 2.287 & 0.104 & 0.480 & 5.863 & - & - & 1.948 & 0.301 & 0.702 \\
\hline HYS2-15 & 17.75 & 0.117 & 0.692 & 1.323 & 0.059 & 0.291 & 3.108 & - & - & 1.023 & 0.322 & 0.654 \\
\hline HYS2-17 & 16.75 & 0.142 & 0.940 & 1.962 & 0.085 & 0.457 & 4.901 & - & - & 1.498 & 0.305 & 0.692 \\
\hline HYS2-18 & 16.25 & 0.093 & 0.557 & 1.164 & 0.050 & 0.299 & 2.897 & - & - & 0.908 & 0.304 & 0.676 \\
\hline HYS2-19 & 15.75 & 0.100 & 0.574 & 1.192 & 0.033 & 0.314 & 3.169 & - & - & 0.918 & 0.296 & 0.691 \\
\hline HYS2-20 & 15.25 & 0.050 & 0.374 & 0.781 & 0.030 & 0.236 & 1.968 & - & - & 0.596 & 0.299 & 0.653 \\
\hline HYS2-21 & 14.75 & 0.065 & 0.448 & 0.887 & 0.036 & 0.280 & 2.268 & - & - & 0.697 & 0.299 & 0.637 \\
\hline HYS2-22 & 14.25 & 0.027 & 0.175 & 0.354 & 0.011 & 0.102 & 0.862 & - & - & 0.283 & 0.307 & 0.642 \\
\hline HYS2-23 & 13.75 & 0.121 & 0.821 & 1.575 & 0.044 & 0.507 & 3.983 & - & - & 1.214 & 0.305 & 0.621 \\
\hline HYS2-24 & 13.25 & 0.115 & 0.917 & 1.775 & 0.044 & 0.596 & 4.602 & - & 0.030 & 1.434 & 0.295 & 0.625 \\
\hline HYS2-25 & 12.75 & 0.063 & 0.559 & 1.040 & 0.029 & 0.329 & 2.537 & - & - & 0.866 & 0.307 & 0.605 \\
\hline HYS2-26 & 12.25 & 0.066 & 0.565 & 1.117 & 0.036 & 0.345 & 2.969 & - & - & 0.964 & 0.288 & 0.652 \\
\hline HYS2-27 & 11.75 & 0.100 & 0.884 & 1.710 & 0.062 & 0.568 & 4.523 & - & 0.026 & 1.456 & 0.289 & 0.633 \\
\hline HYS2-28 & 11.25 & 0.057 & 0.462 & 0.925 & 0.026 & 0.289 & 2.508 & - & 0.013 & 0.797 & 0.284 & 0.660 \\
\hline HYS2-29 & 10.75 & 0.117 & 0.870 & 1.762 & 0.037 & 0.580 & 4.680 & - & 0.025 & 1.509 & 0.287 & 0.648 \\
\hline HYS2-30 & 10.25 & 0.049 & 0.407 & 0.815 & 0.017 & 0.249 & 2.282 & - & 0.013 & 0.682 & 0.282 & 0.674 \\
\hline HYS2-31 & 9.75 & 0.048 & 0.393 & 0.913 & 0.015 & 0.250 & 2.309 & - & 0.011 & 0.711 & 0.291 & 0.700 \\
\hline HYS2-32 & 9.25 & 0.091 & 0.857 & 1.781 & 0.029 & 0.468 & 4.526 & 0.014 & 0.016 & 1.365 & 0.298 & 0.678 \\
\hline HYS2-34 & 8.25 & 0.116 & 0.951 & 2.367 & 0.032 & 0.615 & 5.648 & - & 0.023 & 1.701 & 0.300 & 0.709 \\
\hline HYS2-35 & 7.75 & 0.140 & 1.301 & 3.211 & 0.069 & 0.750 & 7.784 & - & 0.032 & 2.320 & 0.298 & 0.729 \\
\hline HYS2-36 & 7.25 & 0.165 & 1.631 & 4.049 & 0.056 & 1.025 & 10.104 & 0.070 & 0.043 & 3.140 & 0.288 & 0.727 \\
\hline HYS2-37 & 6.75 & 0.131 & 1.262 & 3.659 & 0.033 & 0.767 & 9.375 & 0.023 & 0.040 & 2.944 & 0.277 & 0.808 \\
\hline HYS2-38 & 6.25 & 0.053 & 0.697 & 2.015 & 0.017 & 0.412 & 4.815 & 0.009 & 0.017 & 1.565 & 0.288 & 0.790 \\
\hline HYS2-39 & 5.75 & 0.085 & 0.977 & 2.991 & 0.028 & 0.557 & 7.731 & 0.011 & 0.031 & 2.503 & 0.272 & 0.844 \\
\hline HYS2-40 & 5.25 & 0.089 & 0.728 & 1.627 & 0.028 & 0.462 & 4.133 & - & 0.015 & 1.268 & 0.293 & 0.685 \\
\hline HYS2-41 & 4.75 & 0.054 & 0.579 & 1.862 & 0.012 & 0.363 & 5.040 & 0.013 & 0.020 & 1.636 & 0.260 & 0.865 \\
\hline HYS2-42 & 4.25 & 0.036 & 0.478 & 1.813 & 0.006 & 0.314 & 4.567 & - & 0.013 & 1.460 & 0.268 & 0.907 \\
\hline HYS2-43 & 3.75 & 0.031 & 0.444 & 1.454 & 0.009 & 0.328 & 3.701 & - & 0.012 & 1.097 & 0.273 & 0.825 \\
\hline HYS2-44 & 3.25 & 0.042 & 0.478 & 1.502 & - & 0.310 & 3.583 & - & 0.014 & 1.176 & 0.285 & 0.810 \\
\hline HYS2-45 & 2.75 & 0.064 & 0.580 & 1.765 & - & 0.465 & 4.522 & - & 0.025 & 1.359 & 0.274 & 0.779 \\
\hline HYS2-46 & 2.25 & 0.028 & 0.342 & 0.948 & 0.010 & 0.275 & 2.263 & - & 0.015 & 0.668 & 0.290 & 0.717 \\
\hline HYS2-47 & 1.75 & 0.054 & 0.656 & 1.815 & 0.032 & 0.500 & 4.283 & - & 0.024 & 1.207 & 0.295 & 0.722 \\
\hline HYS2-48 & 1.25 & 0.042 & 0.473 & 1.197 & 0.013 & 0.406 & 2.537 & - & 0.018 & 0.705 & 0.318 & 0.628 \\
\hline HYS2-49 & 0.75 & 0.028 & 0.331 & 0.896 & - & 0.351 & 1.926 & - & 0.022 & 0.534 & 0.307 & 0.617 \\
\hline HYS2-50 & 0.25 & 0.036 & 0.474 & 1.090 & 0.022 & 0.486 & 2.586 & 0.009 & 0.036 & 0.751 & 0.291 & 0.583 \\
\hline
\end{tabular}

a) - below the detection limit. 
northeast of Sichuan and on the eastern edge of the Qinghai-Tibetan Plateau; it has a special geographical position, and is influenced by both the Qinghai-Tibetan Plateau circulation system and the East Asian and Indian monsoons $[20,44]$. For instance, from 1910 to 1940 , the national MAAT rose noticeably $[45,46]$, but this area showed no warming tendency. The lowest winter mean temperature for this area, as identified by tree-rings, has not displayed any obvious tendency to rise [47]. In addition, the indications are that the rising tendency of the MAAT in this area is not completely consistent with that in other areas of China, or globally [45].

During the period 1957 to 2001, the average temperature calculated by $\mathrm{MBT} / \mathrm{CBT}$ was $1.0^{\circ} \mathrm{C}$, close to the average temperature in the last 45 years recorded by the Zoigê Weather Station $\left(0.9^{\circ} \mathrm{C}\right)$ (Figure 4(a), (b), (c) and (d)) [48]. The calculated MAAT values correlate better with the recorded annual mean temperatures $\left(R^{2}=0.324(P<0.05, N=\right.$ 15)) than with the average winter and summer temperatures $(P<0.05, N=15)$ (Figure 4(e), (f) and (g)). However, all the correlations are relatively poor, probably because of the assumption of unvarying sedimentation rates made in the ${ }^{210} \mathrm{~Pb}$-dating constant specific activity model, which causes the calculated time isn't completely identical with the actual time.

The variation range of the calculated MAAT values $\left(5.1^{\circ} \mathrm{C}\right)$ is more significant than that of the instrumental temperatures $\left(1.4^{\circ} \mathrm{C}\right)$ in the period $1957-2001$. When we examined the calibration data set of Weijers et al. [9], we found that the difference and standard deviation between the calculated and instrumental MAATs were $-3.78^{\circ} \mathrm{C}, 5.95$ and $3.42^{\circ} \mathrm{C}, 4.36$, respectively, for instrumental MAAT < $10^{\circ} \mathrm{C}$ and MAAT $>10^{\circ} \mathrm{C}$. This indicates that more precise empirical MAAT equations possibly need to be established for different areas, particularly on a local level, because of the different dynamic processes of soils in different areas of the world, or the different factors influencing the synthesis of branched GDGTs at different latitudes [36].

\section{Conclusions}

We reconstructed the variation patterns of peat $\mathrm{pH}$ and MAAT values in the last 150 years at the Zoigê grassland. MBT/CBT indices related to the distribution of branched GDGTs in the peat core suggest that three periods could be involved. The variation range of the calculated MAAT values $\left(5.1^{\circ} \mathrm{C}\right)$ is more significant than that of the instrumental temperatures $\left(1.4^{\circ} \mathrm{C}\right)$ in the last 45 years; this is probably related to the dynamic features of the local soil. The average temperature calculated by MBT/CBT is close to the average temperature recorded by the Zoigê Weather Station for the last 45 years, and the MAAT value calculated from the $\mathrm{MBT} / \mathrm{CBT}$ indices shows a similar variation tendency to that obtained by tree-rings.
This work was supported by the Knowledge Innovation Program of the Chinese Academy of Sciences (KZCXZ-YW-JC103) and the Foundation for Outstanding Scholarship of Guangzhou Institute of Geochemistry, Chinese Academy of Sciences (GIGRC-09-02).

1 Blackford. Palaeoclimatic records from peat bogs. Trends Ecol Evol, 2000, 15: 193-198

2 Ménot-Combes G, Burns S J, Leuenberger M. Variations of ${ }^{18} \mathrm{O} /{ }^{16} \mathrm{O}$ in plants from temperate peat bogs (Switzerland): Implications for paleoclimatic studies. Earth Planet Sci Lett, 2002, 202: 419-434

3 Hong Y T, Wang Z G, Jiang H B. A 6000-year record of changes in drought and precipitation in northeastern China based on a ${ }^{13} \mathrm{C}$ time series from peat cellulose (in Chinese). Earth Planet Sci Lett, 2001, 185: 111-119

4 Li H, Wang S Z, Leng X T. Progresses in organic geochemical studies on lipids of mires (in Chinese). Bull Mineral Petrol Geochem, 2004, 23: 172-178

5 Tao F X, Liu G S. Extraction of cellulose in geology archives (in Chinese). Bull Mineral Petrol Geochem, 1995, 14: 245-246

6 Lin Q H, Hong Y T, Zhu Y X, et al. The carbon and oxygen isotope composition of modern plants from typical peat bogs in China and its significance on the palaeoclimatic study (in Chinese). Bull Mineral Petrol Geochem, 2004, 20: 93-97

$7 \mathrm{Xu} \mathrm{H}$, Hong Y T, Lin Q H. Temperature variation for the last $6 \mathrm{ka}$ by the oxygen isotope of cellulose in Hongyuan peat (in Chinese). Chinese Sci Bull, 2002, 47: 1181-1186

8 Zheng Y H, Zhou W J, Xie S C. Fossil records of lipid molecules from Holocene peat on Zoigê Plateau (in Chinese). Quat Sci, 2007, 27: $108-113$

9 Weijers J W H, Schouten S, van den Donker J C, et al. Environmental controls on bacterial tetraether membrane lipid distribution in soils. Geochim Cosmochim Acta, 2007, 71: 703-713

10 Sinninghe Damsté J S, Ossebaar J, Schouten S. Altitudinal shifts in the branched tetraether lipid distribution in soil from Mt. Kilimanjaro (Tanzania): Implications for the MBT/CBT continental palaeothermometer. Org Geochem, 2008, 39: 1072-1076

11 Schouten S, Eldrett J, Greenwood D R, et al. Onset of long-term cooling of Greenland near the Eocene-Oligocene boundary as revealed by branched tetraether lipids. Geology, 2008, 36: 147-150

12 Peterse F, Schouten S, van der Meer J, et al. Distribution of branched tetraether lipids in geothermally heated soils: Implications for the MBT/CBT temperature proxy. Org Geochem, 2009, 40: 201-205

13 Schouten S, Hopmans E C, Schefu $\beta$ E, et al. Distributional variations in marine crenarchaeotal membrance lipids: A new tool for reconstructing ancient sea water temperatures? Earth Planet Sci Lett, 2002, 204: $265-274$

14 Weijers J W H, Schouten S, Hopmans E C, et al. Membrane lipids of mesophilic anaerobic bacteria thriving in peats have typical archaeal traits. Environ Microbiol, 2006, 8: 648-657

15 Weijers J W H, Schefu $\beta$ E, Schouten S, et al. Coupled thermal and hydrological evolution of tropical Africa over the last deglaciation. Science, 2007, 315: 1701-1704

16 Weijers J W H, Schouten S, Sluijs A. Warm arctic continents during the Palaeocene-Eocene thermal maximum. Earth Planet Sci Lett, 2007, 261: 230-238

17 Peterse F, Kim J H, Schouten S, et al. Constraints on the application of the MBT/CBT palaeothermometer at high latitude environments (Svalbard, Norway). Org Geochem, 2009, 40: 692-699

18 Gao J Q, Ou Y H, Bai J H. Vertical distribution characteristics of soil labile organic carbon in Ruoergai wetland (in Chinese). J Soil Water Conser, 2006, 20: 76-80

19 Wang H, Hong Y T, Zhu Y X, et al. The peat humification records of Holocene climate change in Hongyuan region (in Chinese). Geo-Geochem, 2003, 31: 51-56

20 Hong B, Lin Q H, Zhu Y X, et al. Carbon isotopic composition of the Carex Mulieensis remain of the Hongyuan peat bog in the wastern Tibetan Platean and the Indian ocean summer monsoon variation in the Holocean. Bull Mineral Petrol Geochem, 2003, 22: 99-103 
21 Wan G J. Progresses on ${ }^{137} \mathrm{Cs}$ and ${ }^{210} \mathrm{~Pb}_{\mathrm{ex}}$ dating of lake sediments (in Chinese). Adv Earth Sci, 1995, 10: 188-192

22 Zhang J, Mou D H, Du J Z, et al. Study on comparison of excess ${ }^{210} \mathrm{~Pb}$ chronology of several models (in Chinese). Mar Environ Sci, 2008, 27: 370-375

23 Wu J L, Li S J, Wang S M, et al. Modern climatic signals recorded in Xincuo Lake sediments in Zoigê basin, eastern Tibetan Plateau, China (in Chinese). J Lake Sci, 2000, 12: 291-296

24 Appleby P G, Nolan P J, Gifford D W, et al. ${ }^{210} \mathrm{~Pb}$ dating by low background gamma counting. Hydrobiologia, 1986, 143: 21-27

25 Hopmans E C, Schouten S, Pancost R D, et al. Analysis of intact tetrameter lipids in archaeal cell material and sediments by high performance liquid chromatography/atmospheric pressure chemical ionization mass spectrometry. Rapid Commun Mass Sp, 2000, 14: 585-589

26 Schouten S, Huguet C, Hopmans E C, et al. Analytical methodology for $\mathrm{TEX}_{86}$ paleothermometry by high-performance liquid chromatography/atmospheric pressure chemical ionization-mass spectrometry. Anal Chem, 2007, 79: 2940-2944

27 Huguet C, Hopmans E C, Febo-Ayala W, et al. An improved method to determine the absolute abundance of glycerol dibiphytanyl glycerol tetraether lipids. Org Geochem, 2007, 37: 1036-1041

28 Weijers J W H, Schouten S, van der Linden M, et al. Water table related variations in the abundance of intact archaeal membrane lipids in a Swedish peat bog. FEMS Microbiol Lett, 2004, 239: 51-56

29 Weijers J W H, Schouten S, Spaargaren O C, et al. Occurrence and distribution of tetraether membrane lipids in soils: Implications for the use of the $\mathrm{TEX}_{86}$ proxy and the BIT index. Org Geochem, 2006, 37: 1680-1693

30 Sinninghe Damsté J S, Hopmans E C, Richard D, et al. Newly discovered non-isoprenoid glycerol dialkyl glycerol tetraether lipids in sediments. Roy Soc Chem, 2000: 1683-1684

31 Schouten S, Hopmans E C, Pancost R D, et al. Widespread occurrence of structurally diverse tetraether membrane lipids: Evidence for the ubiquitous presence of low-temperature relatives of hyperthermophiles. Proc Natl Acad Sci USA, 2000, 97: 14421-14426

32 Kim J H, Schouten S, Buscail R, et al. Origin and distribution of terrestrial organic matter in the NW Mediterranean (Gulf of Lions): exploring the newly developed BIT index. Geochem Geophys Geosys, 2006, 7: 1-20

33 Rueda G, Rosell-Melé A, Escala M, et al. Comparison of instrumental and GDGT based estimates of sea surface and air temperatures from the Skagerak. Org Geochem, 2009, 40: 287-291

34 Hopmans E C, Weijers J W H, Schefu $\beta$ E, et al. A novel proxy for terrestrial organic matter in sediments based on branched and isoprenoid tetraether lipids. Earth Planet Sci Lett, 2004, 224: 107-116
35 Walsh E M, Ingalls A E, Keil R G. Sources and transport of terrestrial organic matter in Vancouver Island fjords and the Vancouver-Washington Margin: A multiproxy approach using $\mathrm{d}^{13} \mathrm{C}_{\mathrm{org}}$, lignin phenols, and the ether lipid BIT index. Limnol Oceanogr, 2008, 53: 1054-1063

36 Tyler J J, Nederbragt A J, Jones V J, et al. Assessing past temperature and soil $\mathrm{pH}$ estimates from bacterial tetraether membrane lipids: Evidence from the recent lake sediments of Lochnagar, Scotland. J Geophys Res, 2010, 115

37 Tierney J E, Russell J M. Distributions of branched GDGTs in a tropical lake system: Implications for lacustrine application of the MBT/CBT paleoproxy. Org Geochem, 2009, 40: 1032-1036

38 Sinninghe Damsté J S, Ossebaar J, Abbas B, et al. Fluxes and distribution of tetraether lipids in an equatorial African lake: constraints on the application of the $\mathrm{TEX}_{86}$ palaeothermometer and BIT index in lacustrine settings. Geochim Cosmochim Acta, 2009, 73: 4232-4249

39 Zink K G, Vandergoes M J, Mangelsdorf K, et al. Application of bacterial glycerol dialkyl glycerol tetraethers (GDGTs) to develop modern and past temperature estimates from New Zealand lakes. Org Geochem, 2010, 41: 1060-1066

40 Guo J, Li G P. Climate change in Zoigê Plateau marsh wetland and its impact on wetland degradation (in Chinese). Plateau Meteorol, 2007, 26: 422-428

41 Zhang B J. Conspectus of exploiting and destroying forest in the westnorth of Sichuan during modern times (1840-1949) (in Chinese). J Kangding Nationality Teachers College, 2008, 17: 40-46

42 Yang Y X, Wang S Y. Human disturbances on mire and peat soils in the Zoigê Plateau (in Chinese). Resour Sci, 2001, 23: 37-41

43 Wang $\mathrm{H}, \mathrm{Wu} \mathrm{K}$. The status and protective of peat bogs and meadows in Hongyuan (in Chinese). Pratacul Livestock, 2009, 3: 37-38

44 Wang Y, Zhao Z Z, Qiao Y S, et al. Paleoclimatic and paleoenvironmental evolution since the late glacial eochas recorded by sporopollen from the Hongyuan peat section on the Zoigê Plateau, northern Sichuan, China (in Chinese). Geol Bull Chin, 2006, 25: 827-832

45 Ding Y H, Dai X S. Temperature variation in China during the last 100 years (in Chinese). Meteorol Monthly, 20: 19-27

46 Wang S W. Global climate warming and its trend in the future (in Chinese). Quat Sci, 1991, 3: 269-276

47 Song H M, Liu Y, Ni W M, et al. Winter mean lowest temperature derived from tree-ring width in Jiuzhaigou region, China since 1750 A.D. (in Chinese). Quat Sci, 2007, 27: 486-491

48 Wang Y, Zhao Z Z, Qiao Y S, et al. Characteristics of the climatic variatation in Zoigê in the past 45 years and its effects on the eco-environment in the area (in Chinese). J Geomech, 2005, 11: $328-333$

Open Access This article is distributed under the terms of the Creative Commons Attribution License which permits any use, distribution, and reproduction in any medium, provided the original author(s) and source are credited. 